\title{
Preliminary studies on the use of Fenton reagent to reduce pollution from wastewater from the production of household chemicals
}

\author{
MACIEJ MALARSKI, JUSTYNA CZAJKOWSKA, PIOTR NOWAK \\ Faculty of Civil and Environmental Engineering, Warsaw University of Life Sciences - \\ SGGW, Poland
}

\begin{abstract}
Preliminary studies on the use of Fenton reagent to reduce pollution from wastewater from the production of household chemicals. Industrial sewage from the production of household chemicals contain large amounts of impurities in the form of ionic and non-ionic surfactants, detergents, active extenders, enzymes. The mixture of these components means that the reduction of pollutants from this type of wastewater is very burdensome. The article presents the results of preliminary laboratory tests of the possibility of using Fenton reaction in the reduction of pollution in wastewater from the household chemistry industry. The reduction of impurities was determined by the concentration of COD. The tests were carried out on samples of wastewater taken from an industrial wastewater treatment plant from the production of household chemistry. A pollution reduction of $24.7-32.3 \%$ was achieved. On the basis of the preliminary tests carried out, the need to better match the doses of reagents to carry out pollution reduction was determined. Despite obtaining values exceeding the limit values for introducing this type of sewage into the sewage system and into the environment, the conducted tests can be considered as prognostic. To compare the process carried out on industrial wastewater, a reduction of impurities was carried out using the Fenton reagent in the standard phenol solution.
\end{abstract}

Key words: Fenton reagent, COD reduction, household chemistry wastewater

\section{INTRODUCTION}

One of the branches of the chemical industry is the production of household chemicals, such as cleaning, washing and disinfecting products. These products in their composition contain, among others: surface active substances, bleaches, fillers, polyphosphate salts, various additional substances affecting the ability to stain, normalization of foaming, prevention of corrosion of washing machines, brightening and preserving colors and causing a pleasant smell (Wang et al. 2004).

During the production of household chemicals, specific wastewater is created, significantly different from municipal wastewater. These wastewater are characterized by high diversity and high content of impurities, which are chemical substances used to produce auxiliary, by-products and final products in household chemistry factory (Wang et al. 2004). The main components included in the discussed household chemistry products that provide the basic cleaning function are:

- surface active substances (ionic and non-ionic) - reduce the surface tension of water, causing it to penetrate 
into the washed fabric and wet the dirt particle;

- detergents - synthetic substances, characterized by high cleaning efficiency even in hard water;

- builders - adding fillers to washing powders aims to increase the effectiveness of washing in hard water (removal of calcium and magnesium ions), dispersion of dirt, binding of heavy metals;

- enzymes - they reduce the energy of activation and are excellent catalysts of the reaction, causing it to accelerate. They also have the ability to break down the insoluble components of dirt on fabrics (Przondo 2010).

It should be remembered that before introducing industrial wastewater to waters or to the ground, as well as before transferring them to a municipal treatment plant, they should be cleaned to the required concentrations of pollutant parameters specified in the Regulation of the Minister of Environment of 2014. Such wastewater discharged into the municipal sewage system can significantly hinder treatment them together with municipal sewage.

The need of environmental protection creates certain difficulties for industrial plants, i.e. more stringent control of the manufactured products, the need of wastewater treatment and sludge treatment, or problems in meeting the requirements of the water permit granted to the plant (Urbanowicz et al. 1999). Wastewater from the industry that does not meet the quality requirements should be pre-treated before entering the sewage system. When discharging industrial wastewater to the receiver, it is necessary to pay attention to adjusting the proc- esses of initial treatment of wastewater to individual requirements (Krzanowski and Wałęga 2007).

Problems for the aquatic environment resulting from the use of household chemicals appear when the wastewater discharged from the industrial plant is not sufficiently treated. Treatment plants should prevent pollution and degradation of receiver water (Kanownik et al. 2016). The household chemicals industry is significantly burdened the environment by discharging wastewater into it, which often contain toxic and hardly biodegradable contaminants. Unknown composition of this type of wastewater and difficulties in their treatment cause that traditional methods are often not so effective to make them safe to the environment. Untreated industrial wastewater is one of the most dangerous threats to natural waters.

There is not one typical composition of industrial wastewater. It depends on the business profile of the factory from which the wastewater is discharged. Special emphasis is placed on the neutralization of industrial wastewater. It often requires complicated and expensive processes (Lenart and Kowalska 2012).

The industrial pollutants various detergents, surfactants and many other substances contained in industrial wastewater, classified as hardly decomposable are often not susceptible to the self-cleaning process. They can remain in the aquatic environment for a long time. Lack of the ability of this type of substances to biodegrade is manifested by toxicity in relation to living organisms, which results in the increase of local fish mortality. Therefore, one of the main pollutants in wastewater from the production of deter- 
gents that is recommended to be monitored is the chemical oxygen demand COD (Wang et al. 2004).

Traditional methods of wastewater treatment are often insufficient. Therefore, there is a need to look for alternative wastewater treatment technologies (Spychała 2016). In the case of industrial wastewater, advanced oxidation processes (AOPs) are increasingly being used. These methods are considered to be effective technologies for wastewater treatment that pose a high environmental burden (Koc-Jurczyk 2012, Mohan 2016). They are considered to be methods with high potential in liquid purification technology (Abouzlam et al. 2015). Advanced oxidation processes methods are characterized by the production of oxidizing agents, which are free radicals, in particular hydroxyl radicals, which have a very large redox potential. One of the examples of the compound used for many years in the AOP method is Fenton's reagent (Barbusiński 2004).

As a result of Fenton reaction, hydroxyl radicals $\left(\mathrm{HO}^{\circ}\right)$ are produced, which belong to the group of the strongest oxidants (Perkowski and Sidor 2007). Hydroxyl radicals are formed during the $\mathrm{H}_{2} \mathrm{O}_{2}$ decomposition reaction with $\mathrm{Fe}$ (II) ions and have a higher redox potential than other oxidants. The hydroxyl radical redox potential is $2.76 \mathrm{~V}$ (Barnusiński 2004). For comparison, the value for ozone is $2.07 \mathrm{~V}$, for persulfate $2.01 \mathrm{~V}$, and for potassium permanganate in the acidic medium $1.68 \mathrm{~V}$ (Cortez et al. 2011, Koc-Jurczyk 2012). The production of hydroxyl radicals is based on the transfer of electrons between hydrogen peroxide and $\mathrm{Fe}(\mathrm{II})$ ions in the catalytic process (Koc-Jurczyk 2012).
The advantage of Fenton reaction is its low economic cost (used reagents are cheap and non-toxic), and the reaction does not require significant amounts of energy and various types of devices, such as ozonators or ultrasound generators. As a result of the Fenton reaction, no chlorinated organic compounds are formed, which can be produced, for example, as a result of chlorination (Włodka-Bergier and Bergier 2011). Often, additional UV radiation is only an assistive element, but not necessary (Koc-Jurczyk 2012). During the Fenton reaction in the treated wastewater, both oxidation of pollutants and coagulation take place. The contribution of these processes depends on the ratio of hydrogen peroxide to $\mathrm{Fe}(\mathrm{II})$ ions. At low $\mathrm{H}_{2} \mathrm{O}_{2} / \mathrm{Fe}$ (II) ratio, the dominant process is coagulation, while with high chemical oxidation (Koc-Jurczyk 2012). In the case of industrial wastewater with a high concentration of contaminants, often difficult to biodegrade, Fenton reaction may be applied before biological purification (Perkowski and Sidor 2006, Perkowski and Sidor 2007, Jelonek and Neczaj 2014).

The aim of the performed tests was to check the possibility of using Fenton reaction in the reduction of pollutants determined by the concentration of COD in wastewater from the household chemistry industry.

\section{RESEARCH METHODOLOGY}

The studies on the reduction of COD concentration of wastewater from the production of household chemistry were carried out at the WULS-SGGW Laboratory of Chemistry and Technology of 
Water and Wastewater. Samples of wastewater were collected from the WWTP of a household chemistry factory, located in Mazovia, after their initial mechanical purification.

The composition of wastewater used for research was not known. Based on the interview conducted at the factory, it was expected that the concentration of COD would be high. Several times of wastewater analysis showed a COD result in the range of 7,677-11,837 $\mathrm{mg} \mathrm{O}_{2} / \mathrm{dm}^{3}$.

The COD reduction tests were carried out in glass beakers placed on electromagnetic mixers at ambient temperature of $20^{\circ} \mathrm{C}$. Due to the unknown composition of the analyzed wastewater from the household chemistry factory and high concentrations of COD (with high variability, depending on the current production in the household chemistry factory), it was assumed that these wastewater may be similar to landfill leachate characterized by high variability and often resistance to biodegradation (Derco et al. 2010, Koc-Jurczyk 2010, Długosz 2014). Hence, in the conducted preliminary tests, established on the basis of the Koc-Jurczyk (2012) study, a dose of iron in the form of $\mathrm{FeSO}_{4} \cdot 7 \mathrm{H}_{2} \mathrm{O}$ was added to the samples in beakers to be a catalyst in the Fenton reaction (Kurt et al. 2017). In all trials, the $\mathrm{Fe}(\mathrm{II})$ dose was constant and was $0.03 \mathrm{~mol} / \mathrm{dm}^{3}$. For the first $20 \mathrm{~min}$, the samples were mixed on magnetic agitators at $500 \mathrm{rpm}$. After complete dissolution of the iron salt, the $\mathrm{pH}$ was adjusted to close to 3 using $\mathrm{H}_{2} \mathrm{SO}_{4}$. According to the literature (Lopez et al. 2004, Deng 2007, Cortez et al. 2010, Umar et al. 2010), at a lower $\mathrm{pH}$ of the liquid undergoing Fenton reaction, a greater reduction of COD is obtained. Next, for the analyzed wastewater samples, a 30\% hydrogen peroxide dose based on the literature (Koc-Jurczyk 2012) was added and the agitator's rotation speed was reduced to about $100 \mathrm{rpm}$ to perform Fenton reaction. After $4 \mathrm{~h}$ of the experiment (duration of the reaction was constant for all doses of hydrogen peroxide) the samples were basified to a $\mathrm{pH}$ of about 12 , interrupting the Fenton reaction. After the agitators were switched off, the suspension was allowed to settle, and then the concentration of impurities was measured in the supernatant liquid.

The hydrogen peroxide added into the samples was in an amount corresponding to $\mathrm{H}_{2} \mathrm{O}_{2} / \mathrm{Fe}$ (II) molar ratios of 3.3 : $1,5: 1,6.6: 1$ and $13.3: 1$. The $\mathrm{FeSO}_{4}$ salt iron in solid form and 30\% hydrogen peroxide were used for the tests. The research was carried out ten times, and the presented results are average values.

In the conducted experiments, the basic indicator of the effect of the use of Fenton reagent was to determine the concentration of COD in the supernatant liquid and to determine the effectiveness of removal of COD. Analytical studies of COD were performed using the titration method by Mohr salt with the use of potassium dichromate as an oxidant in the sulfuric acid medium in accordance with the PN-74/C-04578-03 method.

Additionally, the $\mathrm{pH}$ and iron concentrations were determined in the supernatant liquid. The individual tests were carried out in accordance with the following standards: PN-ISO 6332:2001, PN-EN ISO 10523:2012.

As a comparative experiment and at the same time checking the selected research methodology for reducing COD from wastewater from the household 
chemistry industry, the Fenton reagent was additionally tested for reducing the concentration of COD in the phenol standard solution using the Fenton process. Phenol as a simple organic compound is characterized by the easiness of the COD index reducing (Barbusiński 2004). The experiment used a phenol water solution with an initial concentration of $200 \mathrm{mg} / \mathrm{dm}^{3}$.

\section{RESULTS AND DISCUSSION}

In the research, the reduction of pollutants determined with the COD index from industrial wastewater (sample $\mathrm{S}$ in Table 1) and comparative from the water solution of phenol (sample F in Table 2) with the use of Fenton reagent was carried out. The COD value was reduced from industrial sewage at $24.7-32.3 \%$.
For the obtained average results from tests for industrial wastewater (Table 1), there is a slight influence of increasing the dose of hydrogen peroxide (samples marked from 1 to 4 in Table 1) on an increase in pollution reduction. The test based on the obtained results, determining the ratio of the relation between properties (Pearson linear correlation coefficient $r$ ), gives a value of 0.977 .

The obtained result of the COD concentration reduction at $32.3 \%$ for industrial wastes with the use of hydrogen peroxide $12.22 \mathrm{~cm}^{3} / \mathrm{dm}^{3}$, can be maintained as low.

Perkowski and Sidor (2007) in their research carried out the distribution of selected three surfactants using Fenton reagent and obtained a COD reduction of $80-90 \%$. However, it should be noted, that these studies were conducted on solutions containing single non-ionic sur-

TABLE 1. The results of liquid tests on sedimentary reduction of pollutants from sewage from the household chemistry industry with Fenton reagent (own studies)

\begin{tabular}{|c|c|c|c|c|c|c|}
\hline \multirow[t]{2}{*}{ Sample } & $\begin{array}{c}\mathrm{H}_{2} \mathrm{O}_{2} / \mathrm{Fe}(\mathrm{II}) \\
\text { ratio }\end{array}$ & $\begin{array}{c}\text { COD } \\
\text { (values range) / } \\
\text { / average }\end{array}$ & $\begin{array}{l}\text { COD } \\
\text { reduction }\end{array}$ & $\begin{array}{c}\mathrm{Fe} \\
\left(\begin{array}{c}\text { values range }) / \\
\text { / average }\end{array}\right.\end{array}$ & $\begin{array}{l}\mathrm{Fe} \\
\text { reduction }\end{array}$ & $\begin{array}{c}\mathrm{pH} \\
\text { (values range) } / \\
/ \text { average }\end{array}$ \\
\hline & - & $\mathrm{mg} / \mathrm{dm}^{3}$ & $\%$ & $\mathrm{mg} / \mathrm{dm}^{3}$ & $\%$ & - \\
\hline $\mathrm{S}$ & $\times$ & $\begin{array}{c}(7677-9342) \\
7843\end{array}$ & $\times$ & 31.0 & $\times$ & 8.49 \\
\hline 1 & $3.3: 1$ & $\begin{array}{c}(4898-7308) \\
5891\end{array}$ & 24.9 & $\begin{array}{c}(4.8-24.0) \\
12.4\end{array}$ & 99.5 & $\begin{array}{c}(10.13-11.95) \\
11.58\end{array}$ \\
\hline 2 & $5: 1$ & $\begin{array}{c}(5102-6923) \\
5906\end{array}$ & 24.7 & $\begin{array}{c}(5.4-21.2) \\
10.3\end{array}$ & 99.4 & $\begin{array}{c}(10.23-11.95) \\
11.65\end{array}$ \\
\hline 3 & $6.6: 1$ & $\begin{array}{c}(4082-7308) \\
5805\end{array}$ & 26.0 & $\begin{array}{c}(4.2-20.3) \\
12.3\end{array}$ & 99.3 & $\begin{array}{c}(10.78-11.99) \\
11.43\end{array}$ \\
\hline \multirow[t]{3}{*}{4} & $13.3: 1$ & $\begin{array}{c}(4490-6346) \\
5308\end{array}$ & 32.3 & $\begin{array}{c}(2.2-18.3) \\
12.4\end{array}$ & 99.3 & $\begin{array}{c}(10.29-12.13) \\
11.56\end{array}$ \\
\hline & \multicolumn{6}{|c|}{ Limit value (Regulation of Minister of Environment 2014) } \\
\hline & $\times$ & 125 & $x$ & 10.0 & $x$ & $x$ \\
\hline
\end{tabular}


TABLE 2. The results of liquid tests on sedimentary reduction of pollutants from the phenol solution with Fenton reagent (own studies)

\begin{tabular}{|c|c|c|c|c|c|c|}
\hline \multirow[t]{2}{*}{ Sample } & $\begin{array}{c}\mathrm{H}_{2} \mathrm{O}_{2} / \mathrm{Fe}(\mathrm{II}) \\
\text { ratio }\end{array}$ & COD & COD reduction & $\mathrm{Fe}$ & Fe reduction & $\mathrm{pH}$ \\
\hline & - & $\mathrm{mg} / \mathrm{dm}^{3}$ & $\%$ & $\mathrm{mg} / \mathrm{dm}^{3}$ & $\%$ & - \\
\hline $\mathrm{F}$ & $\times$ & 532 & $\times$ & 0 & $\times$ & 8.41 \\
\hline 1 & $3.3: 1$ & 279 & 47.5 & 0.65 & 99.9 & 12.01 \\
\hline 2 & $5: 1$ & 269 & 49.4 & 0.60 & 99.9 & 11.99 \\
\hline 3 & $6.6: 1$ & 260 & 51.2 & 0.40 & 99.9 & 12.21 \\
\hline \multirow[t]{3}{*}{4} & $13.3: 1$ & 240 & 54.8 & 0.35 & 99.9 & 11.98 \\
\hline & \multicolumn{6}{|c|}{ Limit value (Regulation of Minister of Environment 2014) } \\
\hline & $\times$ & 125 & $\times$ & 10.0 & $\times$ & $\times$ \\
\hline
\end{tabular}

factants. Lopez et al. (2004) and Deng (2007) in research conducted on landfills leachate, they have already obtained a lower reduction of pollutants defined with the COD index at the level of 25$-55 \%$. Koc-Jurczyk (2012) also in studies on waste leachates, only with molar ratio $\mathrm{H}_{2} \mathrm{O}_{2} / \mathrm{Fe}(\mathrm{II})$ at 13.3 , obtained a COD reduction of $85 \%$. In the case of smaller molar ratios, the reduction was at a lower level of $13-60 \%$.

In own research with the use of Fenton reagent, was made a reduction of COD on wastewater from production of household chemistry containing many different non-ionic hardly decomposable surface active substances. The results indicate the possibility of using this reagent in the processes of wastewater treatment from the production of household chemistry. However, when comparing the results $(24.7-32.3 \%$ reduction of COD) with literature data (about $85 \%$ COD reduction) it can be assume that the doses of iron salt and/or hydrogen peroxide were not properly selected. Based on the research, it could be concluded that increasing the dose of hydro- gen peroxide would increase the reduction of pollution from wastewater from the production of household chemistry. However, the possibility of an undesired $\mathrm{HO}^{\bullet}$ radical scavenging reaction should be taken into account in the case of too high $\mathrm{H}_{2} \mathrm{O}_{2} / \mathrm{Fe}$ (II) ratio (Tang and Huang 1996). According to Lopez et al. (2004), in the case of Fenton reagent reduction of landfill leachates, the most favorable $\mathrm{H}_{2} \mathrm{O}_{2} / \mathrm{Fe}$ (II) ratio is at level 12. However, this value, depends on the specific composition of the tested supernatant liquid. Probably in own studies to increase the COD reduction from the wastewater from the production of household chemistry, it would be necessary to increase the amount of both components added to the Fenton reaction.

To compare obtained results and, at the same time, check the accepted research methodology, the experiment of reducing the COD concentration in the phenol standard solution using the Fenton reagent was performed. At the same doses of hydrogen peroxide for a simple organic compound which is phenol, only twice as good results were 


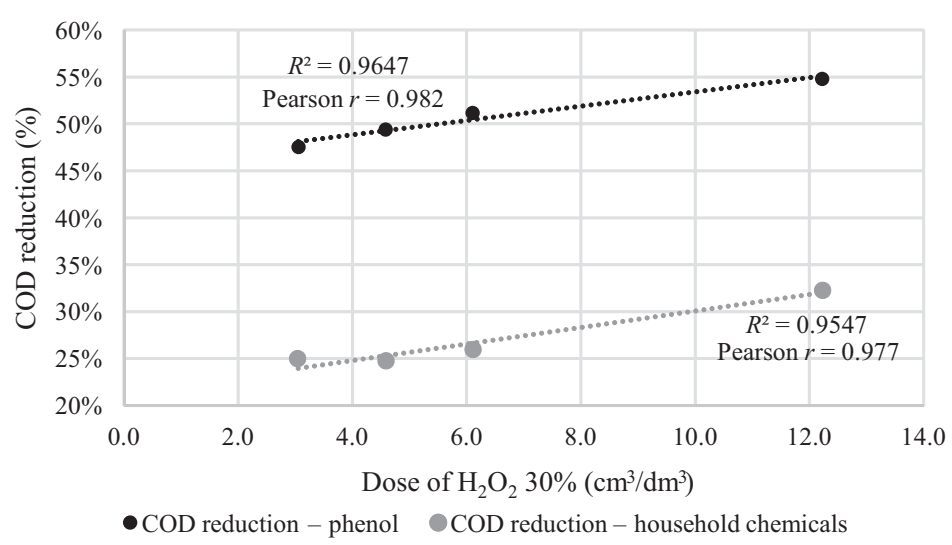

FIGURE 1. COD reduction in sedimentary liquid in relation to a given dose of hydrogen peroxide in experiments with specific trend lines and the coefficient of their determination (own studies)

obtained. The largest reduction in COD $(54.8 \%)$ was obtained using the highest dose $\left(12.22 \mathrm{~cm}^{3} / \mathrm{dm}^{3}\right)$ of $\mathrm{H}_{2} \mathrm{O}_{2}$. For smaller doses of hydrogen peroxide, the efficiency of COD value reducing was gradually decreasing to $47.5 \%$ in the first sample (Table 2). The reduction of phenol at about $50 \%$ from its standard solution may indicate inappropriately chosen proportions and amounts of $\mathrm{H}_{2} \mathrm{O}_{2}$ and $\mathrm{Fe}$ (II), which at the same time confirms the need to select them appropriately for the reduction of COD from wastewater from the production of household chemistry.

Figure 1 shows the decrease in COD index depending on the dose of hydrogen peroxide set in the experiments on industrial wastewater and the phenol solution. Trend lines for which the determination coefficients and correlation were determined are plotted on the graph. In the case of decreasing the value of COD in the experiment on industrial wastewater and the comparative experiment, the coefficients of determination are at the level of $96 \%$, which may suggest a very good fit of the model that maps the dependence in the linear form. However, in the case of the presented preliminary test results and small statistical sample, this statement is not certain. Allows only to suppose the possibility of increasing the dose of hydrogen peroxide in the COD reduction studies.

In the process of contaminants reduction from wastewater using the Fenton reagent, the $\mathrm{FeSO}_{4}$ iron salt was used. It did not participate directly in the COD removal process, but was a catalyst in the production of hydroxyl radicals involved in the removal of pollutants from the wastewater. Therefore, to determine the extent of this reagent consumption in the Fenton reaction, the content of iron concentration in the supernatant liquid was tested.

In the pollutants reduction from industrial wastewater, the iron content in the supernatant liquid decreased to the value between $5.1-16.5 \mathrm{mg} \mathrm{Fe} / \mathrm{dm}^{3}$. Taking into account the initial iron dose set $\left(1.68 \mathrm{~g} \mathrm{Fe} / \mathrm{dm}^{3}\right)$ and its initial concentration value in raw wastewater, its reduction during the experiment was at the level of $99.3-99.5 \%$ in individual samples. There is a noticeable downward 


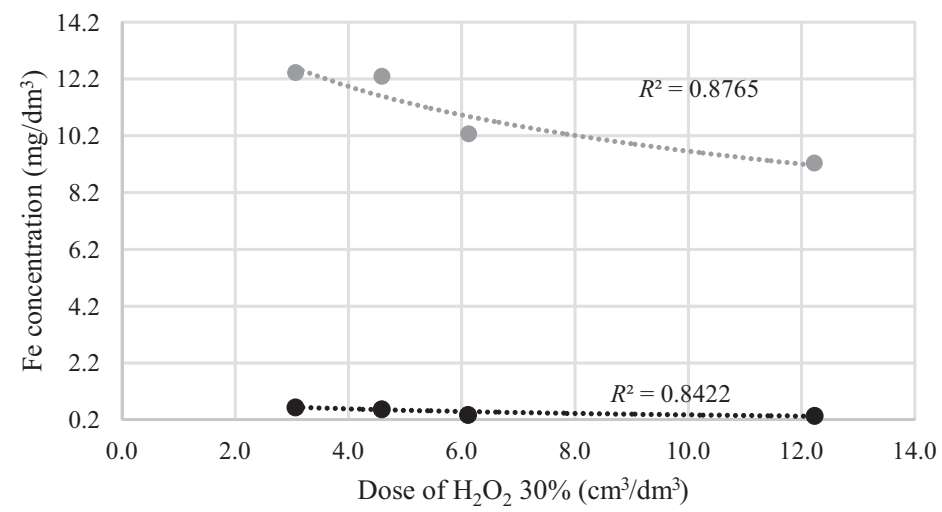

FIGURE 2. Iron reduction in a sedimentary liquid in relation to a given dose of hydrogen peroxide in experiments with specific trend lines and the coefficient of their determination (own studies)

trend in iron concentration along with the increase in the dose of hydrogen peroxide, which is closely related to the consumption of the catalyst for the production of free hydroxyl radicals (HO') in the Fenton reaction (Barbusiński 2004). A higher dose of hydrogen peroxide increases the effects of the oxidation process, including $\mathrm{Fe}(\mathrm{II})$ ions. The iron content in the supernatant liquid in the tested samples ranges from $5.1 \mathrm{mg} \mathrm{Fe} / \mathrm{dm}^{3}$ for the highest dose of $\mathrm{H}_{2} \mathrm{O}_{2}$, successively increasing to $16.5 \mathrm{mg} \mathrm{Fe} / \mathrm{dm}^{3}$, in the first sample with the least amount of added perhydrol. According to the Regulation of Minister of Environment of 2014 the permissible concentration of iron introduced into the environment is $10 \mathrm{mg} /$ $/ \mathrm{dm}^{3}$. The concentration of iron remaining in the supernatant liquid exceeds this value only when using the lowest dose of perhydrol in the studies. The remaining amount of iron in the samples is a potential reagent to produce free hydroxyl radicals for the Fenton reaction.

The comparative experiment performed with the phenol standard solution also shows a similar dependence of the iron concentration in the supernatant liquid to the increasing dose of hydrogen peroxide. In this case, the reduction was at the level of $99.9 \%$ relative to the initial dose set $\left(1.68 \mathrm{~g} \mathrm{Fe} / \mathrm{dm}^{3}\right)$.

Figure 2 shows the iron concentration in the supernatant liquid after the Fenton process depending on the dose of hydrogen peroxide set in the experiments. The charts show trend lines for which determination coefficients have been determined. They are respectively for the experiment on wastewater from the production of household chemistry and on the standard solution of phenol 87.6 and $84.2 \%$. Although they have lower values compared to specific coefficients for removed COD, the presented logarithmic model of the iron content remaining in experiments is defined as a well-reproducible process.

\section{CONCLUSION}

The conducted research confirmed the possibility of using the advanced oxidation process to remove contaminants 
from wastewater from the household chemistry industry. The efficiency of degradation of pollutants was related to the dose of reagents introduced into the wastewater to carry out the process. The highest efficiency of removal of substances determined with the COD index was achieved for the highest $\mathrm{H}_{2} \mathrm{O}_{2} / \mathrm{Fe}$ (II) molar ratio of $13.3: 1$. A decrease in the COD value of $32.3 \%$ was obtained from the industrial sewage tested. The results of wastewater parameters obtained after the experiment do not qualify them for discharge to the environment or sewage system (Regulation of Minister of Environment of 2014, Regulation of Minister of Construction 2016). The obtained value of COD concentrations significantly exceeds the limit value. However, the concentration of iron in the supernatant liquid exceeds the limit value only in the sample with the smallest proportion of $\mathrm{H}_{2} \mathrm{O}_{2} / \mathrm{Fe}(\mathrm{II})$. Sewage with these parameter values should be subjected to further reduction of pollution. Due to the still large amounts of substances difficult to biodegrade, it might be beneficial to carry out the Fenton process again in them.

The literature data show (Tang and Huang 1996, Barbusiński 2004, Lopez et al. 2004, Koc-Jurczyk 2012) that the $\mathrm{H}_{2} \mathrm{O}_{2} / \mathrm{Fe}$ (II) ratio is very important when using Fenton's reagent to reduce pollution from wastewater. Excessive reagents may contribute to reduction of biodegradability of wastewater. However, in the case of analyzed wastewater from production of household chemistry, obtained results of COD in supernatant liquid after the Fenton reaction still have high values of about $6,000 \mathrm{mg} \mathrm{O} / \mathrm{dm}^{3}$, which suggests increasing the dose of hydrogen peroxide for this type of waste- water. At the same time, the analysis of the iron content in the supernatant liquid (Fig. 2) suggests that increasing the dose of iron Fe(II) added as a catalyst in the Fenton process is also likely to improve the efficiency of COD removal.

Analyzing the graph of the decrease in the concentration of wastewater pollutants determined by the COD index in experiments (Fig. 1), a significant difference in the efficiency of the process for experiments is noticeable. However, it should be remembered that the process of reduction of pollutants using the Fenton reaction has been subjected to two different liquids: wastewater from the production of household chemistry containing a mixture of substances hardly decomposable with probably high content of surface active substances and others, and a solution with easily decomposed organic compound phenol solution. Even though the obtained results of the concentration of pollutants in industrial wastewater were non-normative (Regulation of Minister of Environment of 2014, Regulation of Minister of Construction 2016), it can be considered satisfactory as preliminary research to find the parameters of carrying out the Fenton process in order to reduce the concentration of sewage pollutants from the production of household chemicals and increase their biodegradability.

\section{REFERENCES}

ABOUZLAM M., OUVRARD R., POINOT T., MEHDI D., PONTLEVOY F., GOMBERT B., KARPEL Vel LEITNER N. 2015: A gey-box model identification of an advanced oxidation process for wastewater treatment. IFAC-PapersOnLine 48-28: 556-561. 
BARBUSIŃSKI K. 2004: Intensyfikacja procesu oczyszczania ścieków i stabilizacji osadów nadmiernych z wykorzystaniem odczynnika Fentona [Intensification of the wastewater treatment process and stabilization of excess sludge using the Fenton reagent]. Zeszyty Naukowe Politechniki Śląskiej 1603.

CORTEZ S., TEIXEIRA P., OLIVEIRA R., MOTA M. 2011: Evaluation of Fenton and ozone-based advanced oxidation processes as mature landfill leachate pre-treatments. J. Environ. Manag. 92: 749-755.

DENG Y. 2007: Physical and oxidative removal of organics during Fenton treatment of mature municipal landfill leachate. J. Hazard. Mat. 146: 334-340.

DECO J., ŽGAJNAR G., ZAGORCKONČAN J., ALMÁSIOVÁ B., KASSAI A. 2010: Pretreatment of landfill leachate by chemical oxidation processes. Chem. Papers 64 (2): 237-245.

DŁUGOSZ J. 2014: Fenton method and its modifications in the treatment leachate - for review. Arch. Waste Manag. Environ. Protect. 2: 33-42.

JELONEK P., NECZAJ E. 2014: Wstępne badania nad podczyszczaniem odcieków składowiskowych metodą Fentona [Preliminary research on pre-treatment of landfill leachate using the Fenton method]. Inż. Ochr. Środ. 17 (3): 493-502.

KANOWNIK W., POLICHT-LATAWIEC A., WIŚNIOS M. 2016. The effect of purified sewage discharge from a sewage treatment plant on the physicochemical state of water in the receiver. Ann. Warsaw Univ. of Life Sci. - SGGW, Land Reclam. 48 (3): 267-284.

KRZANOWSKI S., WAŁĘGA A. 2007: Wpływ właściwości fizykochemicznych ścieków z przemysłu cukierniczego na aktywność osadu czynnego i efektywność usuwania związków azotu [Influence of physicochemical properties of wastewater from confectionery industry on activated sludge activity and efficiency of ni- trogen compounds removal]. Infr. Ekol. Teren. Wiej. 1: 163-178.

KOC-JURCZYK J. 2012: Efektywność oczyszczania koncentratu odcieków po odwróconej osmozie odczynnikiem Fentona [Effectiveness of purification of reverse-osmosis concentrate of Fenton reagent]. Inż. Ekol. 31: 72-79.

KURT A., MERT B.K., ÖZENGING N., SIVIOĞLU Ö., YONAR T. 2017: Treatment of Antibiotics in Wastewater Using Advanced Oxidation Processes (AOPs). In: R. Farooq, Z. Ahmad (Eds.), Physico-Chemical Wastewater Treatment and Resource Recovery. DOI 10.5772/67538

LENART A., KOWALSKA A. 2012: Wykorzystanie osadu czynnego w oczyszczaniu ścieków. [The use of activated sludge in wastewater treatment]. Kosmos 61, 4 (297): 677-689.

LOPEZ A., PAGANO M., VOLPE A., Di PINTO A.C. 2004: Fenton's pre-treatment of mature landfill leachate. Chemosphere 54: 1005-1010.

MOHAN P. 2016: Study of Fenton Oxidation Process on Dyeing Wastewater and Improving its Catalysis. J. Sci. Eng. Res. 7 (4): 116-123.

PERKOWSKI J., SIDOR M. 2006: Badania rozkładu związku powierzchniowo czynnego Triton X-100 w roztworze wodnym za pomocą odczynnika Fentona [Studies on the decomposition of the Triton X-100 surface active compound in aqueous solution with the Fenton reagent]. Ochr. Środ. 4: 17-24.

PERKOWSKI J., SIDOR M. 2007: Badania rozkładu niejonowych związków powierzchniowo czynnych w wybranych procesach pogłębionego utleniania [Studies on the distribution of non-ionic surfactants in selected deep oxidation processes]. Ochr. Środ. 1: 19-25.

PN-74/C-04578.03. Woda i ścieki. Badania zapotrzebowania tlenu i zawartości węgla organicznego. Oznaczanie chemicznego zapotrzebowania tlenu (ChZT) metodą dwuchromianową [Water and wastewater. 
Research on oxygen demand and organic carbon content. Determination of chemical oxygen demand (COD) by the dichromate metod].

PN-EN ISO 10523:2012. Jakość wody. Oznaczenie $\mathrm{pH}$ [Water quality. Determination of $\mathrm{pH}]$.

PN-ISO 6332:2001. Jakość wody. Oznaczanie żelaza. Metoda spektrometryczna $\mathrm{z}$ 1,10-fenantroliną [Water quality. Determination of iron. Spectrometric method with 1,10-phenanthroline].

PRZONDO J. 2010: Związki powierzchniowo czynne i ich zastosowanie w produkcji chemii gospodarczej [Surfactants and their use in the production of household chemicals]. Wydawnictwo Politechniki Radomskiej, Radom.

Rozporządzenie Ministra Środowiska $\mathrm{z}$ dnia 22 października 2014 r. w sprawie sposobu klasyfikacji stanu jednolitych części wód powierzchniowych oraz środowiskowych norm jakości dla substancji priorytetowych [Regulation of the Minister of the Environment dated 22 October 2014 on the method of classification of the state of uniform parts of surface waters and environmental quality standards for priority substances]. Journal of Laws 2014, item 1482.

Rozporządzenie Ministra Budownictwa $\mathrm{z}$ dnia 28 września 2016 r. w sprawie sposobu realizacji obowiązków dostawców ścieków przemysłowych oraz warunków wprowadzania ścieków do urządzeń kanalizacyjnych [Regulation of the Minister of Construction dated 28 September 2016 on the manner of performing the obligations of suppliers of industrial wastewater and the conditions for the introduction of sewage into sewage systems]. Journal of Laws 2016, item 1757.

SPYCHAŁA M. 2016: Skuteczność filtrów włókninowych do oczyszczania ścieków w warunkach stałego poziomu piętrzącego [Efficiency of nonwoven filters for wastewater treatment in conditions of constant level of bough]. Acta Sci. Pol. Formatio Circumiectus 15 (1): 19-34.
TANG W.Z., HUANG C.P. 1996: 2,4-Dichlorophenol oxidation kinetics by Fenton's reagent. Environ. Technol. 17 (196): 1371-1378.

UMAR M., AZIZ H.A., YUSOFF M.S. 2010: Trends in the use of Fenton, electro-Fenton and photo-Fenton for the treatment of landfill leachate. Waste Manage. 30: 2113-2121.

URBANOWICZ K., RUSZCZYCKA-JAKUBIAKA., KŁOPOTEK B.B. 1999: Substancje niebezpieczne w ściekach z wybranych branż przemysłu chemicznego. Uregulowania prawne, analiza stanu gospodarki ściekowej, strategia ograniczenia emisji [Hazardous substances in sewage from selected branches of the chemical industry. Legal regulations, analysis of sewage management status, emission reduction strategy]. Instytut Ochrony Środowiska, Warszawa.

WANG L.K., HUNG Y.T., LO H.H., YAPIJAKIS C. 2004: Handbook of Industrial and Hazardous Wastes Treatment. $2^{\text {nd }}$ edn., rev. exp. Marcel Dekker, New York.

WŁODYKA-BERGIER A., BERGIER T. 2011: Charakterystyka prekursorów lotnych ubocznych produktów chlorowania wody w sieci wodociągowej Krakowa [Characteristics of the precursors of volatile by-products of water chlorination in the water supply network of Krakow]. Ochr. Środ. 3: 29-33.

Streszczenie: Wstęne badania zastosowania odczynnika Fentona do redukcji zanieczyszczeń ze ścieków z produkcji chemii gospodarczej. Ścieki przemysłowe z produkcji chemii gospodarczej zawierają duże ilości zanieczyszczeń w postaci jonowych i niejonowych substancji powierzchniowo-czynnych, detergentów, wypełniaczy aktywnych, enzymów. Mieszanina tych składników powoduje, że redukcja zanieczyszczeń $\mathrm{z}$ tego typu ścieków jest bardzo uciążliwa. W artykule przedstawiono wyniki wstępnych badań laboratoryjnych możliwości zastosowania reakcji Fentona przy redukcji zanieczyszczeń w ściekach pochodzących z przemysłu chemii gospodarczej. 
Redukcję zanieczyszczeń określono stężeniem wskaźnika ChZT. Badania wykonano na próbkach ścieków pobranych z przyzakładowej oczyszczalni ścieków przemysłowych z produkcji chemii gospodarczej. Uzyskano redukcję zanieczyszczeń na poziomie $24,7-32,3 \%$. Na podstawie przeprowadzonych badań wstępnych określono konieczność lepszego dobrania dawek reagentów do przeprowadzenia redukcji zanieczyszczeń. Mimo uzyskania wartości przekraczających wartości dopuszczalne dla wprowadzania tego typu ścieków do kanalizacji i środowiska, przeprowadzone badania można uznać za rokujące. Dla porównania przeprowadzonego procesu na ściekach przemysłowych wykonano redukcję zanieczyszczeń z wykorzystaniem odczynnika Fentona w wzorcowym roztworze fenolu.
Stowa kluczowe: odczynnik Fentona, redukcja ChZT, ścieki chemii gospodarczej

MS received 10.11.2018

MS accepted 20. 12.2018

\section{Authors' address:}

Maciej Malarski

Katedra Inżynierii Budowlanej

Wydział Budownictwa i Inżynierii Środowiska Szkoła Główna Gospodarstwa Wiejskiego

w Warszawie

ul. Nowoursynowska 159, 02-776 Warszawa

Poland

e-mail:maciej_malarski@sggw.pl 